\title{
国文学作品のテキストデータ記述ルールについて
}

\author{
安 永尚志 ${ }^{\dagger}$
}

国文学作品の電子化テキストのためのデータ記述ルールについて検討した. 様々な国 文学作品の特徵を整理し, 電子化テキストの目的と研究対象をまとめ, 必要なデー夕 記述のための機能や情報構造について考察している，デー夕記述の基本原則を作品の 構造とテキストの構造に分けて考察し，またデー夕表記の様相を分析，評価し，ルー ル化についてまとめている，3つの基本ルールから成る KOKIN ルールと呼ぶデー夕 記述文法を定義し，作成した。これは国文学作品を対象とする電子化テキスト記述用 のマークアップ文法である，ルールに基づく電子化データを実際に作成し，ルールの 構文の正当性やルールの有用性などについて評価している，例えば，電子化データの テキストデータベースや CD-ROM への登録, SGML への変換などを行っている。こ れらの結果，ルールの有効性が確認され，実用性についても高く評価された。

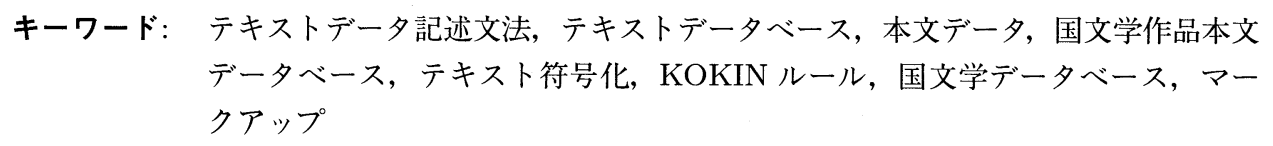

\section{Text Data Description Rules for Japanese Classical Literature}

\author{
HISASHI YASUNAGA ${ }^{\dagger}$
}

This paper describes a study on the text-data description rules for the Japanese classical literature. We have investigated the various functions for the text-data description by analyzing the research on the Japanese literature. As the results, we have found that it is necessary to consider the following three characteristics. These are the recognition and definition of the data structure for the literary works or books, of the text structure, and of the various features in the Japanese writing style. We have defined and developed the rule with three functions, called as the KOKIN-rule. This is the markup rule for encoding and composing of the electronic text on the Japanese literature. Many electronic texts have been defined based on the rule, such as a series of short stories, 21 Tanka anthologies, etc. Then, it is widely evaluated for the texts as the consistency and availability on the data description. Particularly, we have confirmed that it can be applicable to the other researches, such as the organization of text databases, registration to CD-ROMs, and conversion to the SGML standard.

KeyWords: Text-Data Description Rules, Full-Text Database, Text data, Full-text Database for Japanese Literature, Text Encoding, KOKIN Rules, Japanese Literary Databases, Mark-up

$\dagger$ 国文学研究資料館研究情報部, Department of Research Information, National Institute of Japanese Literature 


\section{1 まえがき}

最近, 国文学の分野においても, 文学作品のテキストをコンピュータに入力し, 研究に活用 しようとする動きが盛んである (DB-West 編 1995)。これは日本語処理可能なパソコンなどの 普及により，国文学の研究者が，自分の手でデー夕を作成する環境が整ってきたことによるす でに, 多くの文学作品が電子化テキストとして作成され, 蓄積され, 流通され始めてきている.

例えば，村上ら (村上 1989) による語彙索引作成を目的とした幸若舞の研究は，最も初期の ものである。これは田島ら（田嶋・星野 1982）により，万葉集を始めとする多くの文学作品の 電子化テキスト作成の試みに引き継がれている。最近では, 内田ら (内田 1992) は情報処理語 学文学研究会の活動を通じて, パソコン通信などにより電子化テキストの交換を行っている. また，伊井，伊藤ら (伊井 1993; 伊藤 1992) による国文学データベースの作成と電子出版活動 も注目されている，とくに，源氏物語諸本の 8 本集成データベースや国文学総合索引の研究成 果がある. 一方, 長瀬 (長瀬 1990) は源氏物語の和英平行電子化テキストを作成し, オックス フォード大学に登録し公開した。また，出版社による電子化テキストの提供サービスも始まっ ている (勉誠社 1993; 岩波書店 1995).

しかしながら，大きな問題がある，一般に，研究者は自分のためのデータを作っている．そ のため, システム, 文字コード, 外字処理, データの形式や構造などに関しての仕様が, 研究 者個人に依存している.さらに，蓄積した情報資源の流通をあまり意識していない。すなわち, 苦労して蓄積したデー夕が活用されにくく，また同じ作品の重複入力の問題などが指摘されて いる.

したがって, データ入力の共通基盤の確立と適切な標準化が必要である．とくに，文学作品 の電子化テキストを作るためのデー夕記述ルールが必要である. 現在, 人文科学のための定まっ たデー夕記述のルールは無い. SGML：Standard Generalized Markup Language (JIS 1994)に 基礎をおく TEI:Text Encoding Initiative などの活動 (Burnard 1994) があるが，その成果は未 だ実用化に至っていない。とりわけ，人文科学領域の日本語テキストへの適用は，国文学にお ける数例 (Hara and Yasunaga 1995) を除けばほとんど無い.

国文学研究資料館において，電子化テキストのデー夕記述についての試みがなされてきてい る (Yasunaga 1992; 安永 1994, 1995a; 国文学研究資料館編 1992). 例えば，日本古典文学大系 (岩波書店)，噺本大系（東京堂出版）などの全作品の全文データベースの開発が進められてい る。また，最近では正保版本歌集「二十一代集」を直接翻刻 ${ }^{1}$ しながら，データベースに構築し ている。これらはテキストのデータベース化を指向したものであるが，テキストデー夕の記述 のための基準文法が定められている。この基準文法を KOKIN (KOKubungaku INformation) ルールと呼んでいる．KOKIN ルールは国文学作品を対象とする電子化テキスト記述用のマー

1 国文学の用語はまとめて, 付録 A で解説している.なお，国文学ではテキストを本文（ホンモン）と言う．以下では本 文を用いる。 
クアップ文法である。

本稿は, 国文学作品テキストのデー夕記述文法について述べている，第 2 章では，電子化テ キストの目的と研究対象をまとめ, デー夕記述の考察上不可欠と考えられる本とテキストの情 報構造を分析し，まとめている．第 3 章では, データ記述のルール化のための基本原則を考察 している．作品とテキストの構造記述が必要なこと, 及びテキスト表記の記述が必要なことな どをまとめている，第 4 章では，KOKIN ルールを 3 つの基本ルールに分けて定義し，それぞ れについて考察している，第 5 章では，実際のデー夕作成とそれに基づくデータベース作成の 事例などから，KOKIN ルールを評価している。研究成果としては，すでに国文学研究資料館 において, 本文データベースとして試験運用が開始されている。研究者による利用結果からは, 文学研究に有用であるとの評価を得, 概して評判がよい. 最後に, 問題点などを整理している.

\section{2 電子化本文作成のための条件整理}

\section{1 電子化本文の目標}

電子化本文の作成は研究の効率化をはかることが目的であるが, 新しい研究テーマへの展開 やデータベースとしての発見的利用も期待されている，例えば，大量の資料，情報を扱った考 察が可能になり，自説の組立や確認の度合いが飛躍的に高まる。単語や語形の検索はもとより， 単語が現れる環境の調査が可能になる，組版などの印刷物では表せないことが可能になる』さ らに，作品に記載されていないことの発見的検索が可能になる (近藤 1991).

国文学の研究対象は, 上代の神話から現代の作品まで全ての時代に渡り, 地域的にも歴史上 のわが国全土を網羅する。また, 古典文学は千数百年に渡る歴史を持ち, ジャンルも多様であ る. 表 1 に, 散文, 韻文, 戯曲のカテゴリに大別し, その代表的ジャンルの例を示す. しかし, 絵詞のよjにこの分類に馴染まないものも多い.

表 1 国文学作品のジャンル区分

\begin{tabular}{|c|c|}
\hline カテゴリ & ジャンル \\
\hline 散文 & $\begin{array}{l}\text { 神話, 伝承, 風土記, 縁起, 史書, 軍記, 物語, } \\
\text { 説話, 論評, 随筆, 日記, 紀行 }\end{array}$ \\
\hline 韻文 & 歌謡, 和歌, 連歌, 俳諧, 漢詩, 和讃, 今様 \\
\hline 演劇 & 能, 狂言, 歌舞伎, 浄瑠璃, 催馬楽 \\
\hline その他 & 祝詞, 声明, 宣命, 談義, 絵詞, 絵解き \\
\hline
\end{tabular}

このような様々な作品を統一的に電子化することは不可能である.そこで, 次のような段階 を経ながら，電子化の経験を積むこととした。 
第 1 段階: 時代，ジャンルを網羅するような基準本文を作る.

第 2 段階: 個別のジャンルまたは作品の深化を行う.

これは，まず国文学作品の全般的な様相を知り，次いで個別の作品の伝本の全ての本文校訂 に進むことを可能とするプロセスを考えるためである，したがって，第 1 段階での網羅性は文 学作品の本文の全体的な様相を把握し，その上で電子化の方策を考えることが可能な程度の作 品の種類と量を必要とする。また，これには実際にデー夕を作成し，その過程から知識を得て 行くことが不可欠である.

また，写本や刊本から直接電子化本文を作ることはかなり難しい. 規範的な標本があれば， あるいは典拠と言って良いが，作業効率は格段に高まる．研究者が最も望むものは，第 2 段階 の専門領域の電子化本文である，基準本文は第 2 段階の電子化本文作成にとって，重要な要件 と考えられる。

何を基準とするかの問題がある．国文学や歴史学では古記録，古文書，古典籍などの研究対 象資料（文献資料と言う）を翻刻する場合に，校訂作業が不可欠である。作品の多くの伝本を 比較参照し，書写文字などによる本文の意味や用法を考察し，作品の本文を定める（定本と言 う）。すなわち，校訂本が作られる。このことから，基準本文には定本としての校訂本を基礎と すべきである。

現在までに研究対象とした作品の一覧を, 表 2 に示す。これらは二十一代集を除き, 校訂 本からのデー夕作成である，第 1 段階として，時代及びジャンルを網羅した規範的な校訂本の データベースを準備することを目標にして，選定している。

\section{2 電子化本文の情報構造}

\subsection{1 本文と本の情報構造}

電子化本文を作成するに当たって，まず取り扱う情報の種類と性質を整理する必要がある。 本文は校訂本から選んだ。このとき，この本文は校訂という枠組の中で成立する。すなわち， 電子化本文は純粋な本文デー夕の他に，校訂に関する情報を持つ必要がある．本文デー夕が単 独で利用されることはない，本文とその本に関する情報は不可分である。

困 1 に，このような情報を階層的に構造化して示す。これは本と作品，本文の情報構造を明 確化し，その上で本の論理構造を定義するものである．国文学におけるこのような整理はなく， 困 1 はや、常識的ではあるが，現在有用であるとされている.

ここで，本と作品の物理構造を考えておく，本は作品を記載する。この関係は通常は 1 対 1 であるが，古典籍では多対 1 あるいは逆に 1 対多も多い. 多対 1 は作品が分冊される形態であ ク，1 対多は複数の作品がまとめられる場合である。これは伝本の形態によって異なる．この ような情報構造は図 1 によって記述できる。ささらに，よく和歌集などに見られる合緅本などの 構造記述も可能である。なお，本文が文献資料から直接選ばれる場合も，実質的に翻刻，校訂 
表 2 本文データベースの研究対象作品

\begin{tabular}{|c|c|c|c|c|}
\hline 校訂本 & $\begin{array}{c}\text { 日本古典文学大系 } \\
\text { 岩波書店 }\end{array}$ & $\begin{array}{c}\text { 噺本大系 } \\
\text { 東京堂出版 }\end{array}$ & $\begin{array}{l}\text { 假名草子集成 } \\
\text { 東京堂出版 }\end{array}$ & $\begin{array}{c}\text { 正保版本歌集* } \\
\text { 二十一代集 }\end{array}$ \\
\hline 作品数 & $\begin{array}{l}\text { 全 } 100 \text { 巻 } \\
\text { 約 } 560 \text { 作品 }\end{array}$ & $\begin{array}{l}\text { 全 } 20 \text { 巻 } \\
380 \text { 作品 } \\
\text { 約 } 2 \text { 万噺 }\end{array}$ & $\begin{array}{l}\text { 全 } 12 \text { 巻 } \\
70 \text { 作品 } \\
\text { 約 } 1 \text { 千話 }\end{array}$ & 全 21 作品 \\
\hline 文字数 & 約 3 千万字 & 約 700 万字 & 約 400 万字 & 約 150 万字 \\
\hline 外字数 & $\begin{array}{l}\text { 約 } 3 \text { 千字 } \\
\text { 約 } 600 \text { 字** }\end{array}$ & $\begin{array}{c}\text { 無し } \\
\text { (絵文字などを除く) } \\
\end{array}$ & $\begin{array}{c}\text { 約 } 100 \text { 字 } \\
\text { (絵文字などを除く) }\end{array}$ & 無し \\
\hline 備考 & $\begin{array}{l}\text { ・校訂本 } \\
\text { ・時代, ジャンルを } \\
\text { 網羅する規範的 } \\
\text { 本文 }\end{array}$ & $\begin{array}{l}\text { ・校訂本 } \\
\text { ・江戸前期, 中期の } \\
\text { 小話集 } \\
\text { ・ 小噺の類型化な } \\
\text { どに最適 }\end{array}$ & $\begin{array}{l}\text { - 校訂本 } \\
\text { - 室町期, 江戸前期 } \\
\text { の説話集 }\end{array}$ & $\begin{array}{l}\text { ・版本である } \\
\text { ・翻刻と同時に, デ } \\
\text { ータベース化 }\end{array}$ \\
\hline
\end{tabular}

〈注〉

* 校訂本ではなく，版本である.

** 国文学研究資料館作成 JIS 外字を除く，作成すべき外字の概数. なお, 文字数は概数で示す.

作業を経るから，図 1 の情報構造が適応できる.

\subsection{2 本の情報構造}

困 1 (a) は，本の構造を示す．本の構造は本の物理的なモノとしての種類と形態を表す。本 は伝来されたものである。これを本の系譜構造として把握する。また，本の情報とは本に関わ る情報，言わば属性情報であり，階層化して定義する。

本の情報構造は 3 レベルの階層で定義する，図において，本の情報は文献資料情報と校訂本 情報とから成る。

文献資料情報は底本, 諸本（または異本とも言う），それらの系譜に関わる情報から成る。ま た，底本情報は書誌，所蔵，及び成立に関する情報から成り，諸本情報も同様である。書誌，所 蔵に関わる情報は図書館などで一般に用いられている情報に加え，古典籍特有の情報項目を持 つ，成立情報は底本及び諸本の本文の成立に関わる情報である，通常，校訂は底本を基軸とし 他の伝本を参照しながら行われる。すなわち，底本は諸本の中で位置付けられる，位置付けに 関わる情報は本の成立に関わる構造の把握と考えられる。

一方，校訂本情報は本としての構造を持ち，書誌情報などによって同定される，校訂本には 成立に関する情報は無いと考えられるが，ここでは一般化して考える. 同一の作品には複数の校 訂本があるが，校訂本としての性格から独立して扱うことは可能である．ただし，文献資料情 
（a） 本の構造 本の系譜構造
文献資料（伝本）
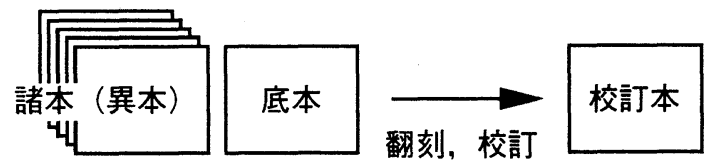

翻刻, 校訂

底本 諸本（異本）

校訂本（翻刻本を含む）

(本文データの対象)

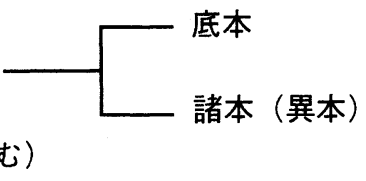

文献資料 (伝本)

本の構造

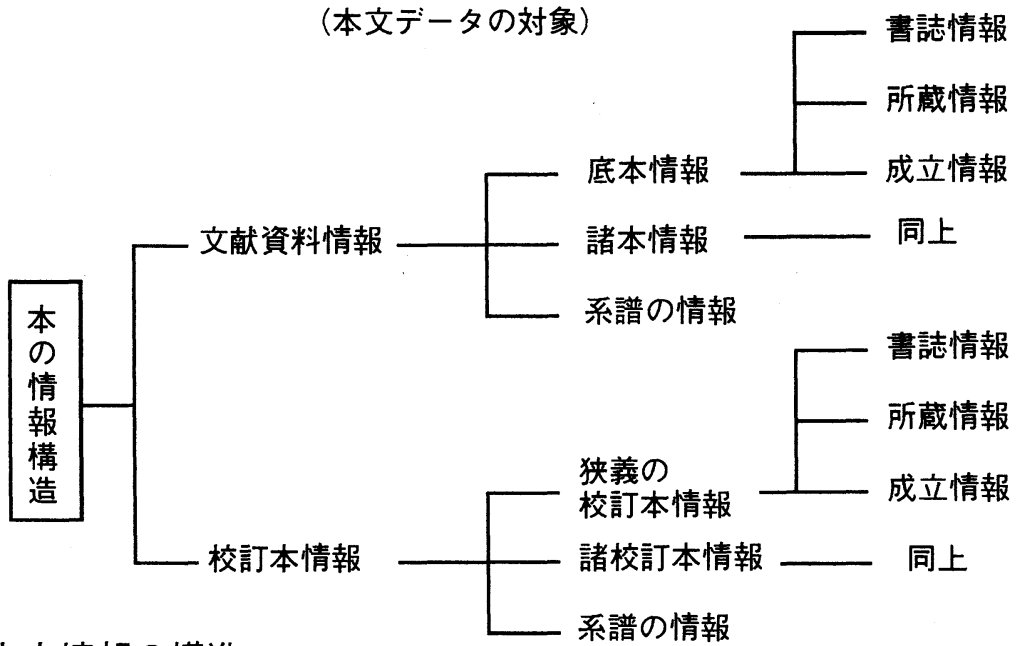

（b） 本文情報の構造 系譜の情報

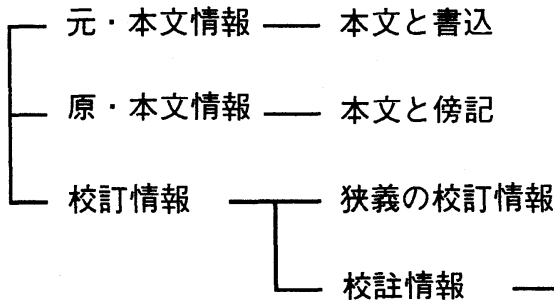

（c） 本の論理構造

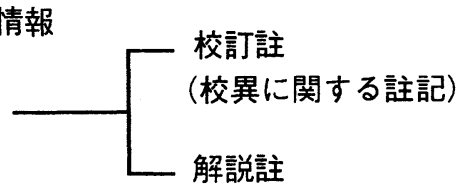

（事項に関する解説）

論理原本 論理ファイル 論理レコード

原本 原文 原行 原語 原字

図 1 電子化本文の情報構造の解析と定義 
報と同様に諸校訂本との関連を参照する必要がある場合には，諸校訂本情報として記述する ${ }^{2}$.

\subsection{3 本文の情報構造}

図 1 (b) は，本文に関する情報の構造である。本文情報は元・本文情報, 原・本文情報, 及 び校訂情報から成る，本文情報はその出典により，2種類に大別される，両者は全く異なるも のである。

元・本文情報とは底本に記載されている本文と, それへの種々の書き込みなどの情報である. 書肆的な情報なども含む. 校訂により，元・本文情報は校訂本文である原・本文情報に变換さ れる。

原・本文情報は本文と傍記の形式で表記される。ここで，本文とは主たるテキストを指す。 傍記は本文を構成する文, 語, 字などへ直接付加されたテキストである. 例えば, 校異, 振り仮 名や振り漢字などがある.

また, 校訂本には作品の本文の他に校訂に関わる様々な情報を伴う。例えば, 解題, 解説, 頭 註または脚註，凡例などである。これらを校訂情報と呼ぶが，単なる註ではなく校訂本のテキ ストの形態の 1 つである，ところで，校訂情報は狭義の校訂情報と校註情報と呼ぶ 2 つの情報 から成る，狭義の校訂情報は解題などのように作品全体に関わる情報であり，テキスト形態の 1つである，校註情報は頭註など本文の語彙などに関わる情報である，上述の傍記とは異なる ものである。

さらに，校註情報は校訂註と解説註に分けて考える，校訂註は本文の異同に関する校訂者の 見解や従来の考え方などの参照である，校異に関する註記であるので，校訂上とくに重要な情 報と考えられる，解説註は主に本文中の様々な事項に関する解説である。例えば, 人物, 儀式, 官位，あるいはテキストの解釈などである。いずれもテキスト形態の1つと考えられる。

\subsection{4 電子化本文の論理構造}

図 1 (c) に示すように, 論理的な原本の構造を定義する. 電子化の直接的な対象は原本すな わち校訂本である，原本はその版面情報を保存することを原則とする．理由は電子化本文の根 拠を原本において，データの信頼度を保証する必要があるためである。すなわち，原本通りの データがデータベースに写像されていなければならない.

そこで, 原本を論理化して考える，論理原本は論理ファイルから成る．すなわち，原本の各 ページを論理ファイルとして定義する．論理ファイルは原本のそのぺージに限定された原文の 集まりである．通常, ページや原行の始端または終端では文の中断が起こり得る.これを認識 したり，また意味のある文の単位を確定したりすることは結構難しい。

2 以下，底本に関する用語には “元”を付し，校訂本に関する用語には “原”を付して，混乱を避ける。例えば，底本で はその本文を元・本文とし, 校訂本はその本文を原・本文とする，また，校訂本を原本と呼び，その行を原行，語を原 語などと呼ぶ。 
文の単位を形式的に定義する，原文は形式的に原行の集合から構成されるから，論理ファイ ルは原行から構成するものとする，すなわち，文を行によって形式的に定義する．これを論理 レコードと呼ぶ。論理レコードはまた原語及び原字から構成される．論理ファイル中の論理レ コードは順序性を保存し，かつ論理ファイル自体も順序性を持つ ${ }^{3}$.

以上のことから，電子化本文のデー夕記述においては，本の構造，作品の構造，本への作品 の位置付けなどを考慮しなければならないことが分かった，また，本文を構成する文，語，字 などの要素に対応する傍記と呼ぶテキスト形態の1つを, 本文記述としてルール化しなければ ならない.

\section{3 本文のデータベース化指向}

文学研究には本文とそれに関わる諸情報が，同時に参照，処理できなければならない。これ は，全文をコンピュータに単に蓄積しただけでは進められない。本文情報のデータベース化を 指向する必要がある，全文と様々な属性情報から成る総合的なデータベースを，校訂本文デー タベースと呼ぶ。

電子化本文は本文と傍記から成るが，これは並列的なテキストである．また，校訂情報や校 註情報などが加わり，マルチテキストである，とくに，本文は諸本の系譜の中で位置づけられ， 諸本の本文比較などが可能でなければならない. 本文の氏素性の関連と同定に関する多種多様 な情報を組織化し，活用しなければならない。

すなわち，このような多重構造を持ったデー夕の世界は，データベースとして構築すること が適当と考えられる.さらに，研究者の研究目的，方法，対象によって自由な活用ができるこ とが不可欠である。例えば，ハイパーテキストなどのユーザインタフェースにより, 柔軟かつ 高次の活用に応える必要がある。

このことから，まず大型コンピュータのデータベース機能を活用し，本文データベース化の 基本的開発研究を行うこととした. この成果に基づき, 次いでパーソナルデータベース化を進 める.パーソナルデータベースではデータの流通を考慮して，例えば CD-ROMなどのパッケー ジ型の自立型テキストを考虑する。

なお，デー夕記述のルールにはデータベース化を指向した機能を考慮する必要がある.

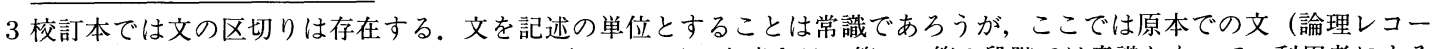
ド）の位置付けを重視した，文，あるいは語などへの分かち書きは，第 1 ，第 2 段階では意識しないで，利用者による ものとしている. 


\section{3 デー夕記述のための基本原則}

\section{1 本文の構造}

\subsection{1 作品の構造}

文学作品の構造を定義しなければならない, 通常, SGMLでは文書型定義 (DTD:Document Type Definition）と呼ばれるもので，ここではこれを作品型定義（TTD:Text-data Type Definition）と呼ぶ。一般に, TTD は全てに共通するような標準型が定義できるわけではない，韻 文, 散文, 戯曲の文体毎に, さらに細かいジャンル対応に TTD を定義する必要がある。すな わち, 作品毎に TTD を置く。なお，現在一般に定まった本文 DTD またはTTD は無い。

本文研究では，作品の掲載されている原本の体裁などの情報が必要とされる．例えば，原本 の何ページの何行目の文という同定が必要である。これは, 諸本の本文の様々な差異の対比に おいて必要とされる。通常, SGMLでは文書の構造を論理的なものとして本の体裁, すなわち フォーマットを分離して考える. しかし, 古典テキストの研究では, 本の物理的な構造と論理 的な構造を一体化した考え方をとることが要求される，すなわち，本文の位置情報が必要であ る。ある本におけるその文の現れる位置の同定である.

原本に記載されている底本の位置情報も不可欠な情報である，例えば，表 2 の噺本大系では 原・本文中に「(十五ウ)」などと表記されているが，これは「この位置までが底本の 15 枚目の 裏であること」を意味する.

ところで, 底本の文, 語, 字などと校訂本の文, 語, 字などとの対応は, 研究上不可欠な情 報として同定されなければならない，換言すれば，写本のテキストと活字本のテキストの文の対 応，同定である。しかしながら，このデー夕作成は専門家によるかなり高度な作業を必要とす る.しかも，作業の負荷がたいへんに重い。そのため，この課題は将来課題とせざるを得ない。

以下の考察のために, 図 2 に, 表 2 の東京堂出版「噺本大系」の第五巻「軽口大わらひ」の 版面コピーを示す. また, 図 3 に噺本大系の作品構造を 5 レベルの階層構造で定義する例を示 す.なお，記号などは後述する。

\subsection{2 本文の構造}

次に, 本文の構造を把握しなければならない。いわゆる文体である。当然, 本文の構造は ジャンルにより異なり, 同じジャンルでも時代や本の体裁により異なる.

原・本文は多くの文から構成されている．文には多くの種類がある．デー夕記述に当たって， 文を 1 つの単位とすることが望まれるが，意味のある文の確定は困難である，そこで，前述の ようにデー夕記述の基本的単位を論理レコードとした.

論理レコードの識別のための記述子をタグと呼ぶ。論理レコードは原本上の位置を保存し，

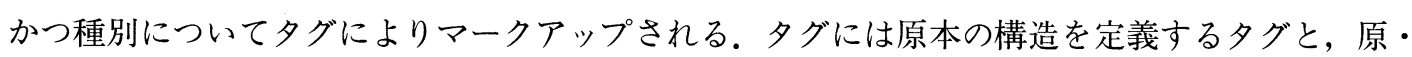




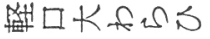

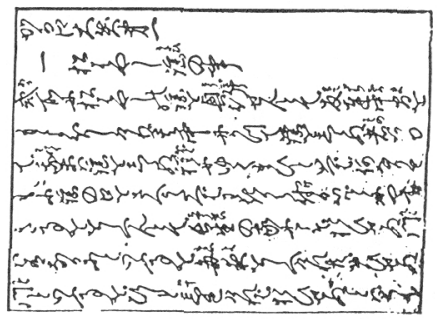

期脯人姑厈 寻粗什计

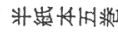

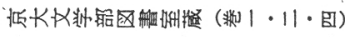

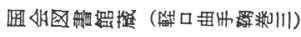

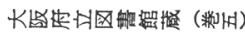

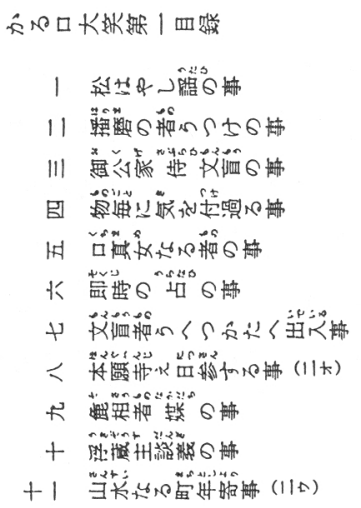

athon (1)
H人

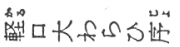

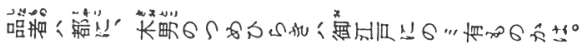

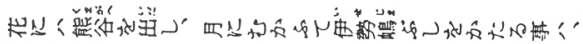



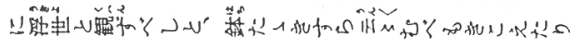

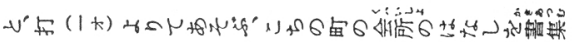







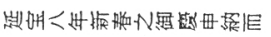

洍6區出

$$
\text { 三 断小品 (ID) }
$$

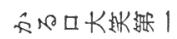



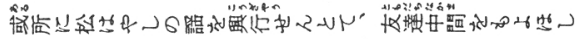





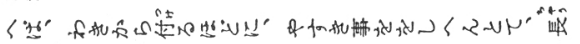

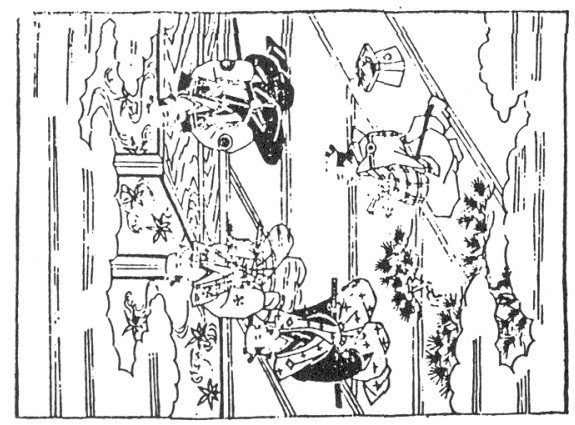

th

図 2 「噺本大系」第五巻「軽口大わらひ」の版面例 


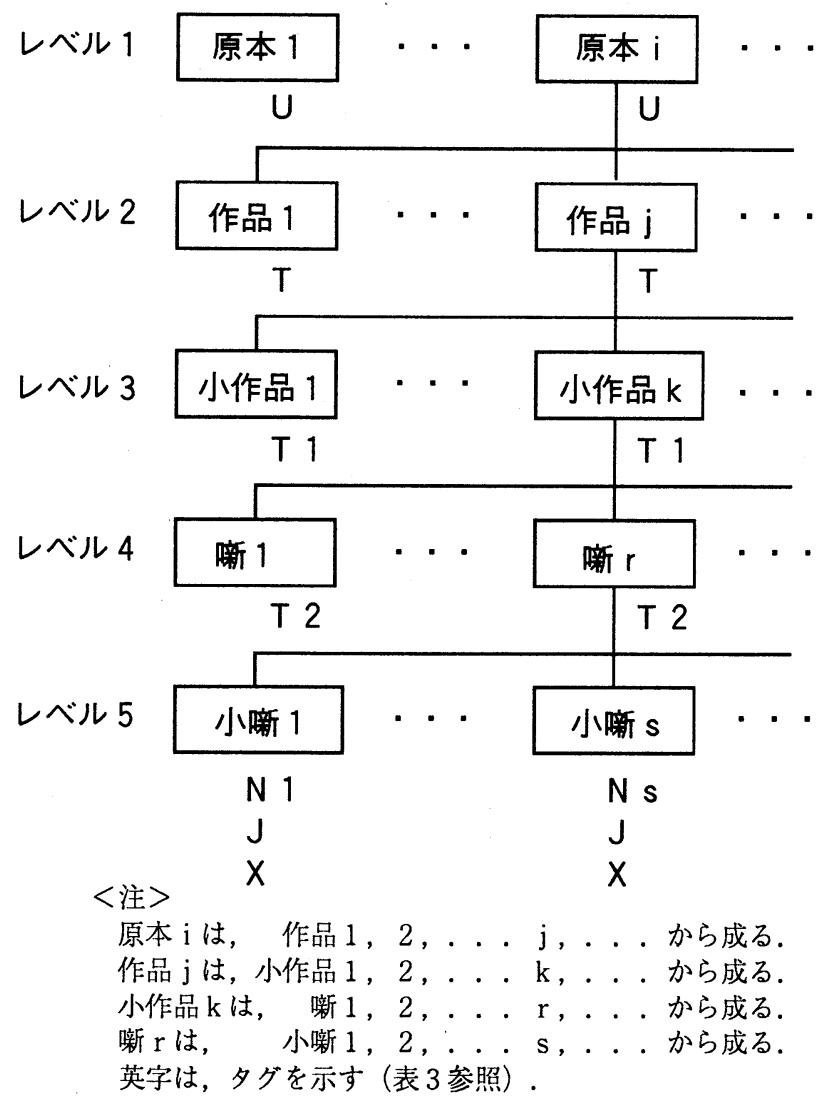

図 3 噺本大系の作品構造の階層性

本文の構造を定義する夕グがある．論理レコードの順序性は夕グにより保持する.

意味のある論理レコードの集まりを定義する。論理レコード集と呼ぶ. 例えば，和歌集の中 の 1 つの歌の範囲を決める論理レコードの集まり，すなわち作者，題，詞書き，歌などのまと まりである。あるいは，図 3 に示すような小噺の 1 つの単位などである.

論理ファイルは形式的な論理レコードの集まりとして取り扱う。一方，論理レコード集は上 例のように意味のある構造を抽出する場合に用いる. 


\section{2 本文表記の構造}

\subsection{1 表記の様相}

現代文，古文を問わず日本語には欧米文と異った特有の表現がある．文は分かち書きの無い 文であり，とくに古文では句読点も無い.

文は縦書きであり, 割書, 虫喰い, 囲みがあり, 読み, 振り, 訓点, ヨコト点, 各種註記などの 多様な傍記を持っている. さらに, 任意の位置に参照や書込みがあり, 挿し絵, 解題, 頭註ま たは脚註があり，系図があり，「何々を見よ」などの引用や遷移もある。すなわち，作品は本文 と。各種情報が混在したハイパーテキスト的である（図 2 の版面参照）.

\subsection{2 フラグ方式}

原・本文は本文と傍記によって表現される。本文の記述には文字セットを除き特段のルール は必要ではない，傍記の記述にはルールが必要である。一般に，傍記はその文の要素への指示 として表される。文の要素を本文素と呼ぶ. 本文素とは意味のある語や字を単位とする概念で はなく，傍記の対象となる語や字などの論理的な単位である．傍記は必ずしも意味のある語に 指示されるわけではなく, 例えばその語にとって意味的に不可分の下位構成語や字に指示され ることも多い，傍記の表記は本文素に対する並列的なまた補足的な文や記号から成る。これを 傍記素と呼ぶ。

したがって，本文素に対する傍記の位置付けが決まればその記述が可能である。この位置 付けの記述子はフラグと呼ばれる。フラグは本文素並びに本文素の間に対する傍記の位置を示 すために使用する．本文素の間とは字間や語間などであり，傍記はこれらの間にも指示される. これにより，傍記を論理レコード中に埋め込み記述することができる.

一方，特殊な構造を持つ文の表記形式については，フラグを構造的に定義する制御記号を定 め，その変換規則を定める。これらには虫喰いとその各種変形，図式的なテキスト表現（系困 など），割書， 2 重傍記，版本における書誌的事項などが定義されている.

\subsection{3 文字セット}

文字種が多い，本文は書写による時代による複雑な変遷，伝搬過程がある．電子化本文の文 字セットを閉じることは不可能である. 文字セットには梵字などの各国語文字, 踊り字, 謡印, 音曲記号, 注記記号などの他, 絵文字に代表されるような特殊な文字や記号もある.

原文に使われている文字セットは原則として保存する，ただし，踊り字，謡印などのような 特殊な文字や記号は, 適切な文字や記号に置換する。

例として, 日本古典文学大系を見てみる。これは旧漢字, 旧仮名使いで表記されている. 現 在の JIS コード表（JIS 78 を用いている）では漢字字体についての規則性はなく, 旧字体と新 
字体が混在している，そのため，JIS コード表に定義している旧漢字はそのまま使う。 JIS 外 の旧漢字でその新字体が JIS 内にある場合はこの新字体を用いる。その新字体が JIS 外であれ ばその文字を作成する，JIS 外字の内，新字体を持なない旧字体の漢字は作成する，国文学研 究資料館が定義する JIS 外字（約 2600 字）は基本文字として使う.

このような簡単な規則を定めて電子化した場合に，日本古典文学大系には約 3 千種の JIS 外 字がある．この内の約 600 種は作成すべき文字と認識されている，ただし，デー夕流通を考え る場合にはあまり JIS 外字を増やすべきではない。なお，噺本大系は JIS 内字に拠っているの で，JIS 外字はないが，この場合には絵文字などの特殊文字が多い.

使用する文字セットはその型を TTDの先頭で定義する。

\section{3 付加価値づけ}

国文学の電子化本文に要求される機能に，まず語彙索引の作成がある．日本語による文は語 単位の分かち書きの無い文からなる。そこで，日本語の全文データべースを作成する場合は， その文を分かち書きしなければならない,さらに，その単位毎に表記, 読み, 品詞などの属性 情報を付加する必要がある。しかし，分かち書きを行うことは一般に容易ではない.

次のような問題がある。作品は時代, ジャンルの範囲が広範である，また，作品は個々に文 体が異なるために, 語彙索引の作成, 管理, 利用の取扱いが異なる. 最も重要な点は, 研究者 によって語単位の確定やその属性に対する認識が異なることである.

したがって，第1段階では分かち書きをしたデー夕作成は行わない．利用する研究者が行う ものとする。そのための分かち書きと属性付加に関するルールのみを定める.

\section{4 データ記述文法 一 KOKIN ルール}

\section{1 前提}

上記の問題を全て解決できているわけではない，電子化本文の対象は前述の校訂本，版本で あるから, 符号化の規則はこの範囲を原則としている. KOKIN ルールと呼ぶデー夕記述文法 を定め, データ作成に当った。これは自立型のデータファイルとして流通できること, 並びに 本文データベースに登録できることを条件にしている，KOKIN ルールは 3 種の規則から成る．

なお，この規則は研究者が日常的に使用できることを前提に作られており，単純ではあるが 機能は充足していなければならない，以下に，ルールの基本構造をまとめる．文献 (安永 1995b) による噺本大系を具体例に用いる。 


\subsection{KOKIN ルール \# 1}

KOKIN ルール＃1 は作品の TTD を定義する．TTD は論理ファイルの順序並びである. 論理ファイルは論理レコードの順序並びである。論理レコードはその型と性質が夕グにより定 義される。したがって，TTDの定義は夕グリストで表すことができる．なお，タグを持たない 論理レコードはない.

図 4 に，論理レコードの基本形を多少説明を省くが BNF で定義したものを示す. 論理レ コードの基本形は夕グと情報部から構成される。情報部は原文の本文データの本体部分であり， 算用数字または日本語文字列で表現される。

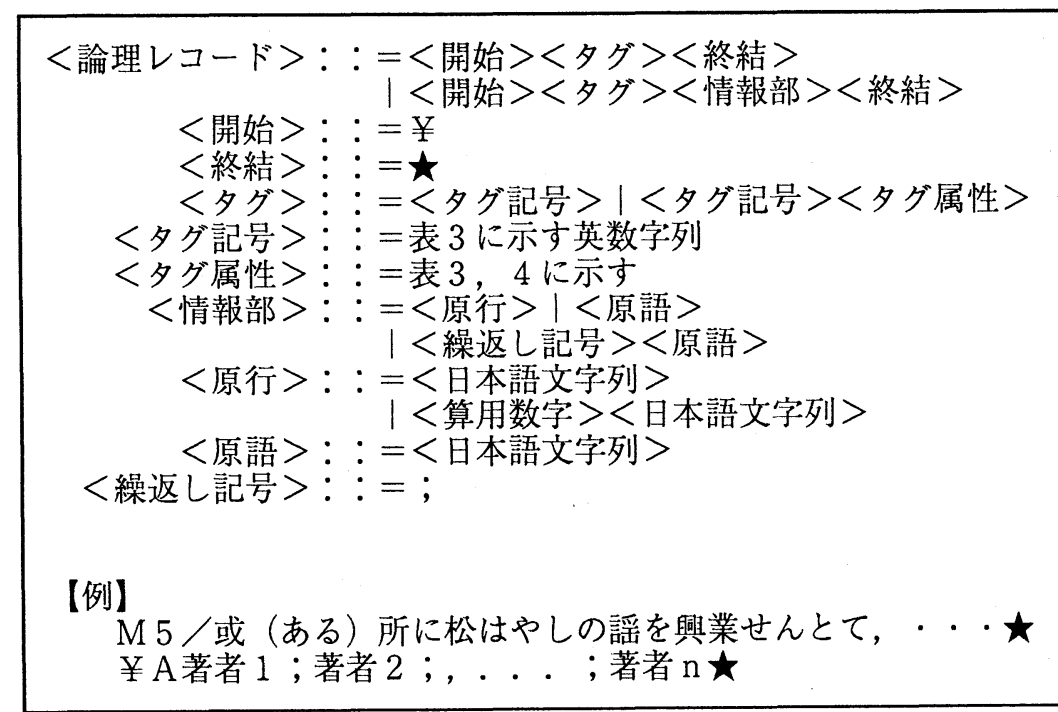

〈注＞開始は，例に示すように省略を許す場合がある. タグ属性は，実装時には表 3，4 亿示すように, 情報部の中で扱う。

図 4 論理レコードの基本形 (BNF による) - KOKIN ルール \# 1

表 3 に，夕グの種類と定義の抜粋例を示す．また，表 4 に夕グの書式と文法の定義例を示す. タグは英字により定義し, 属性は算用数字 (いずれも全角文字), または日本語文字列による.

原則として，論理レコードは開始記号“¥”で始まり，タグを定義し，必要な情報部による 本文データが続き, 終結記号 “`”で終了する，自明の開始記号は省略可とする．これらの記 号に特段の意味はなく, 利用者の見た目の分かり易さを重視した. なお, 作品毎に独自に定義 するタグがある。これをローカルルールと呼ぶ. 
表 3 噺本大系の夕グ (論理コード) の一覧

(1) 原本の構造を定義する夕グ

\begin{tabular}{l|l}
\hline \multicolumn{1}{c|}{ タグ } & \multicolumn{1}{c}{ 役割, 備考 } \\
\hline $\mathrm{U}$ & 原本名称 \\
$\mathrm{P} \mathrm{n}$ & 論理ファイル名称 \\
$\mathrm{Ln}, \mathrm{Mn}$ & 論理ファイルを構成する原行論理レコード. \\
& 本来は, 原本文の構造を定義する夕グであるが, \\
& 原本の構造を決める基本的単位である. \\
\hline
\end{tabular}

(2) 原本文の構造を定義する夕グ (抜粋)

\begin{tabular}{|c|c|}
\hline 夕グ & 役割, 備考 \\
\hline $\mathrm{T}$ & 作品名称 \\
\hline $\mathrm{T} 1$ & 子作品名称 \\
\hline $\mathrm{T} 2$ & 噺名称 \\
\hline $\mathrm{X}$ & 小噺名称，小噺の題名 \\
\hline $\mathrm{N} n$ & 小噺の順序番号 \\
\hline $\mathrm{J}$ & 小噺のキイワード \\
\hline $\mathrm{Y}$ & 作品の書誌的事項 \\
\hline Y 1 & 小作品の書誌的事項 \\
\hline Q & 作品の奥書事項 \\
\hline Q 1 & 小作品の奥書事項 \\
\hline $\mathrm{G}$ & 挿し絵の名称, 挿し絵の位置を同定する. \\
\hline $\mathrm{g}$ & 原文中の挿し絵の名称, 挿し絵の位置 \\
\hline $\mathrm{g} \mathrm{n}$ & 挿し絵中の本文 \\
\hline $\mathrm{H}$ & 表形式の四表の名称, 困表の位置 \\
\hline $\mathrm{h}$ & 原文中の表の名称, ’表の位置 \\
\hline $\mathrm{h} \mathrm{n}$ & 表中の本文 \\
\hline A & 噺, 小噺の作者名 \\
\hline $\mathrm{B}$ & 噺, 小噺の出典などの補足事項 \\
\hline $\mathrm{L} \mathrm{n}$ & 原行論理レコード. 原本の 2 段組版の上段 \\
\hline $\mathrm{Mn}$ & 原行論理レコード. 同上の下段 \\
\hline
\end{tabular}

〈注〉 $\mathrm{n}$ は, 夕グの属性值. 算用数字列で順序性を持つ.

噺本大系に関する作品構造（TTD）の定義例を，付録 B に示す。また，そのデー夕記述例 （初期データ入力例）を，噺本大系第五巻「軽口大わらひ」について，付録 C に示す.

\subsection{KOKIN ルール\# 2}

KOKIN ルール\# 2 は，日本語の特有な表記のためのデー夕記述のルールである. 主として 傍記記述の文法である，傍記はテキストであるが，本文に対する付随的な情報と考え，意味を 考えない，例えば，読み，振り漢字，校異註，参照などの区別をしない，すなわち，本文に対す る傍記の位置付けである論理関係を定義する。この記述子がフラグである，図 5 に， BNF に 
表 4 夕グの書式と文法の定義 (抜粋例)

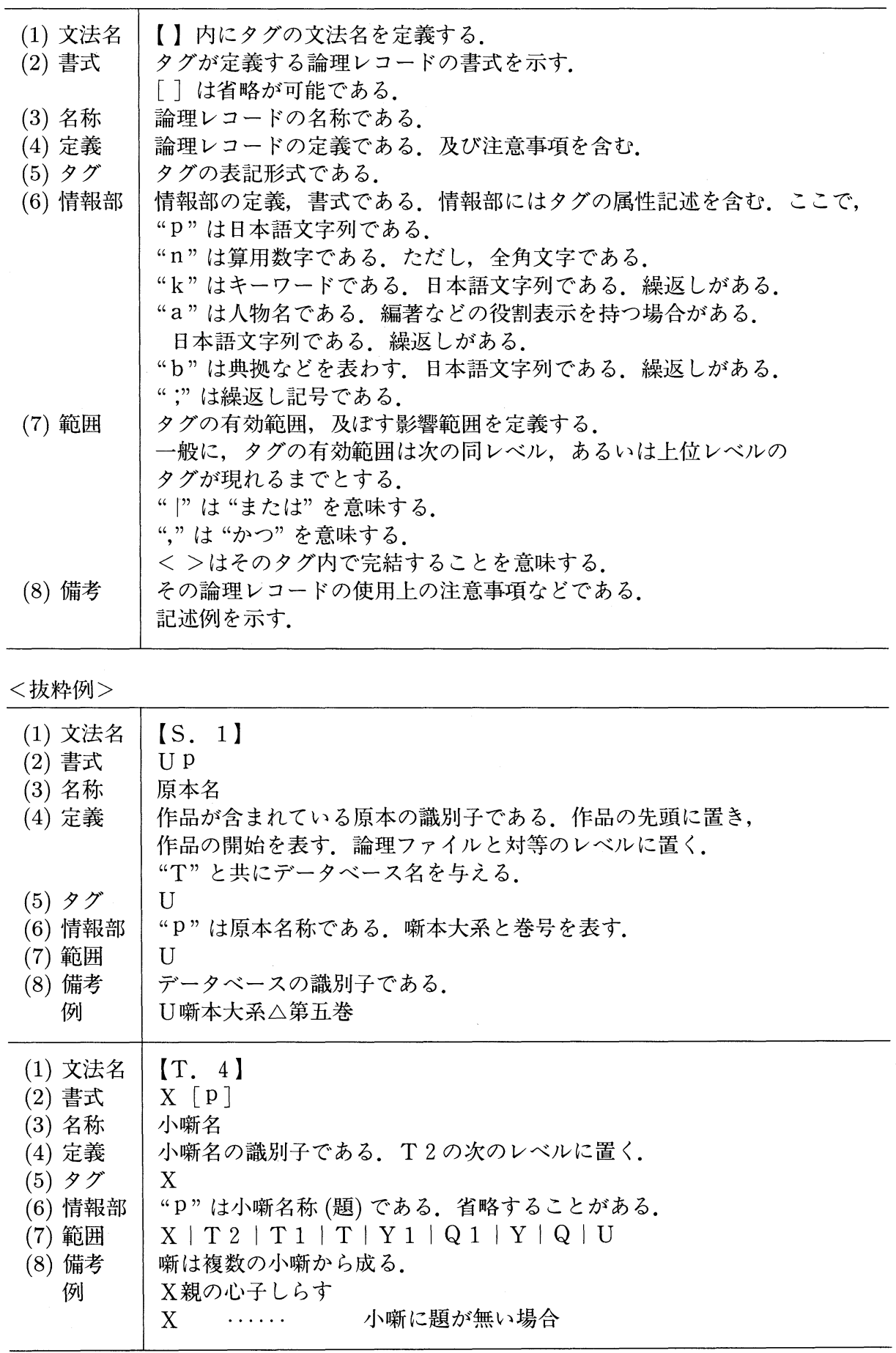


よりフラグ文法を定義した抜粋例を示す。また，下記で用いる例を図中にまとめる.

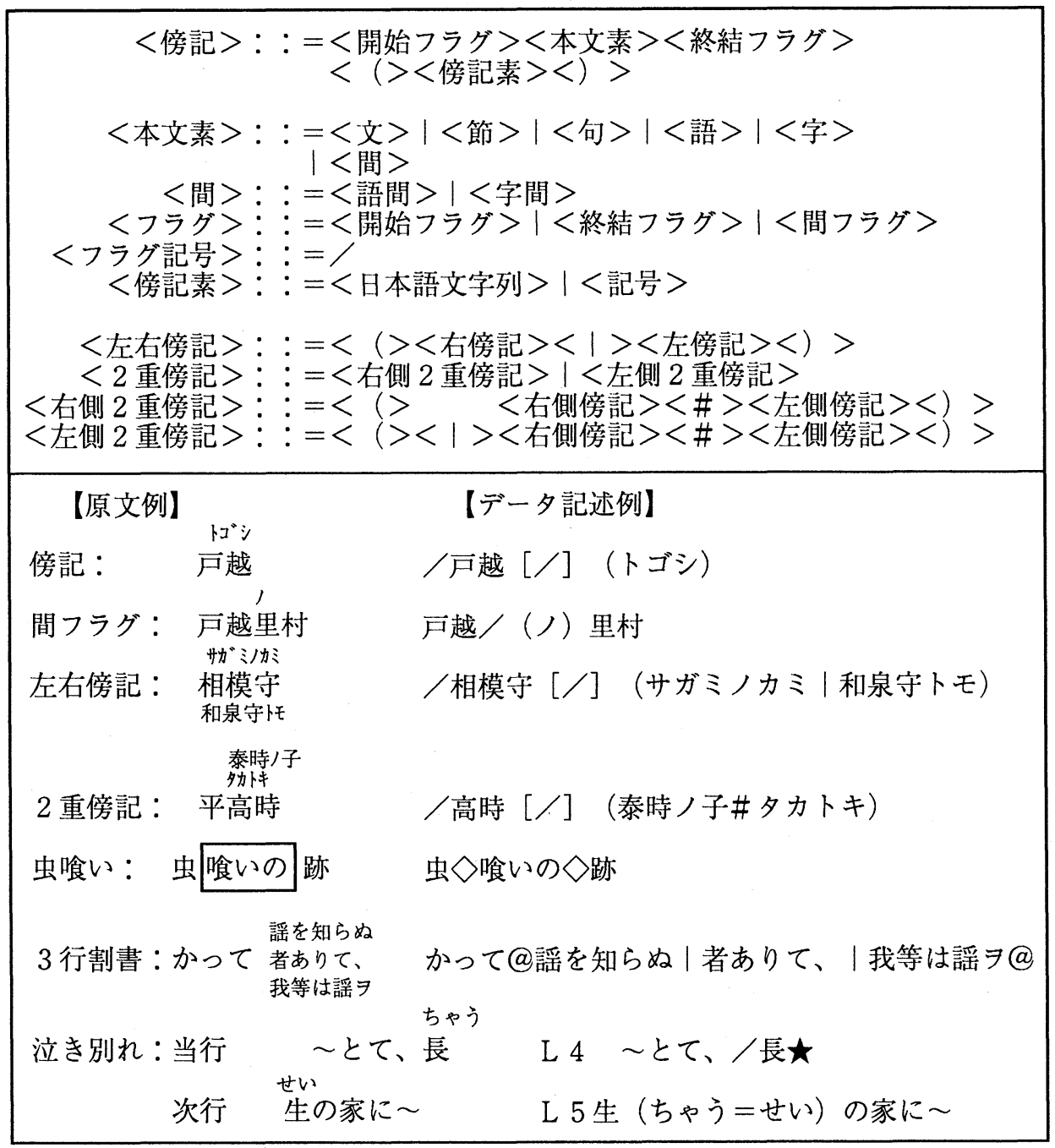

〈注＞［］は, 省略可能である. 3 行割書, 泣き別れのルールは省略.

図 5 フラグの基本形 (BNF による) - KOKIN ルール\#2

フラグは, 本文素への傍記の位置の開始及び終結を指示しなければならない。これらを開始 フラグ及び終結フラグと呼ぶ。終結フラグに続いて開始フラグが現れる場合は, 終結フラグを 省略することができる（フラグの縮約と言う）。とくに，字間，語間などの間の位置を示すフラ グは開始と終結を同時に兼ねる。これを間フラグと呼ぶ。なお，間フラグに続いて開始フラグ 
が現れる場合（傍記が独立している）は，フラグの省略は無い.

特殊な傍記などの記述のための制御記述子を定義する．以下に代表例（記述例は図 5 ）を示 す．縦書である本文素の左右の傍記を左右傍記と呼ぶ。左右傍記制御記述子“”により，右傍 記と左傍記を識別する。記述順序は右傍記優先である。 2 重傍記は 2 重傍記制御記述子“\#” により識別する．記述順序は右側傍記優先である.

文の特殊な表記の記述規則も定める，例えば，虫喰いは様々な表記形式がある．個別の虫喰 いは原則として文字 “四”に置き換える，四角で囲った虫喰い文字列は，推量された文字列を 補ったものである，虫喰い領域記述子“○”により記述する，同様に，領域を指定する記述子 はそれぞれの性質毎に定める。例えば，割書は領域記述子“@”により識別する。

傍記データの記述規則を定める，傍記データは原文のままとする．傍記には，元来底本に 表記されている振り仮名や漢字などがあり，また原本の校異などに関する種々の校訂註がある. デー夕記述においては傍記の種類の区別はしない。すなわち，傍記の属性情報は定義しない.

特殊文字の置換規則を定める，例えば，古文でよく使われる 2 字以上の踊り字“〈”は，清 音, 半濁音, 濁音別に定める繰返し記号により置換する。例えば, $\mathrm{n}$ 字の清音の踊り字はnを 繰返し音字数とし，“+ n”と記述する.

\subsection{KOKIN ルール\# 3}

分かち書きを行い, 品詞情報や各種属性情報を付加するための規則である，付加価值付けと 呼んでいる，ルール化の基礎を語彙索引の作成に置くすすなわち，文を語あるいは接辞などの 造語成分に区切り（語単位），これに対する読みを付して，読みによる50音順に配列する．同 一語を一ヶ所に集めるために，活用語は終止形を基本とする読みを与える，さらに，同音異義 語を区別するため漢字を与える．掛詞などの両用語の掲出を考慮する．品詞情報を付加する． とくに, 名詞では人物名, 官職と人物の同定, 地名の同定を考慮する.一方では, 原文の誤字, 脱字などや特殊語彙の注記の表現なども必要である.

図 6 に，ルールの典型例を示す. KOKIN ルール\# 2 と同様の書式であるが，フラグ記号に 空白を用いて語単位（または形態, 形態素など）を確定し（）内に属性情報を付す。属性情報 は語単位に対して，種別を［］尔どで括り与える。属性情報の記述は傍記と同じ形式である.

語単位の確定や属性情報の種類と目的などは, 研究者の研究目的によって異なるから，これ ら全てについて前もって定義することはできない。このような背景から，ルール～ 3 は現在未 完成である．また，先に述べたように，第 1 段階では分かち書きは行わない. 


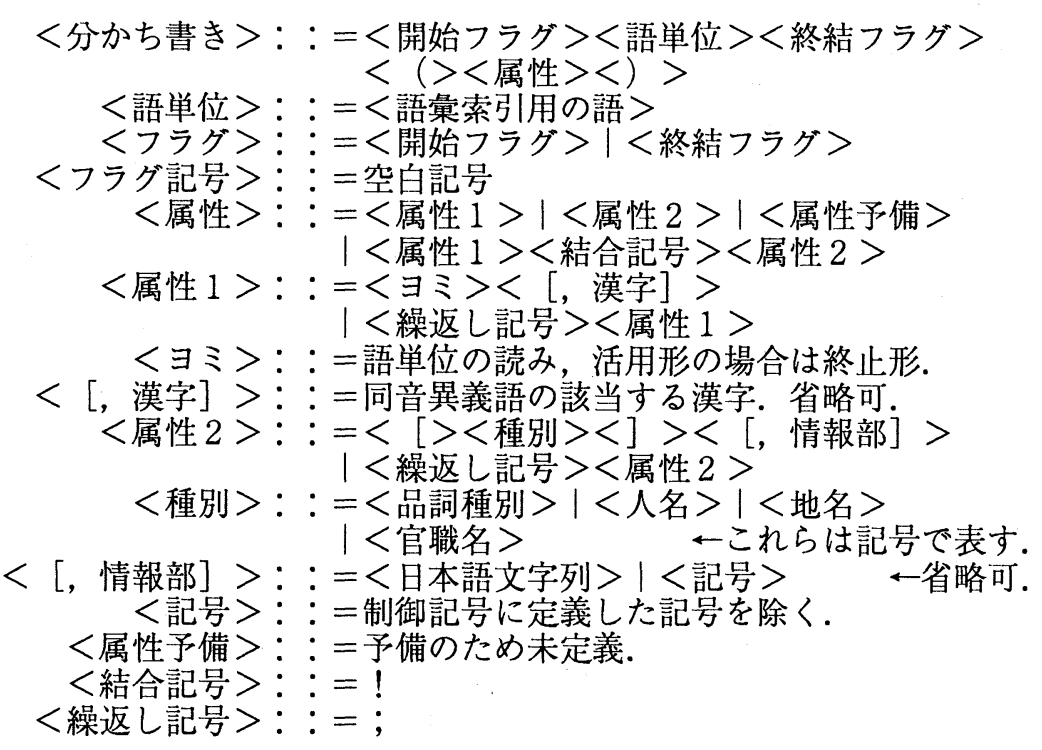

〈注＞KOKIN ルール\#3による例は示さない. 現在, 未完成である.

図 6 付加価值付けの基本形 (BNF による)-KOKIN ルール\# 3

\section{5 評価}

KOKIN ルールに基づいて, 表 2 に示す作品のデー夕記述を行い, デー夕作成を行った.こ れらのデータ構文の正当性の検証は，専用のパーサシステムを作り確認した。詳細は割愛す るが，KOKIN ルール自体に特段の問題はない。このシステムはむしろデー夕作成上のエラー チェックに有効であった. また，ルール化されたデータから元のデータを再現する検証を行い， 確認した.これは印刷組版までの再現ではなく，原本の形式上の再現として行った。

次に，KOKIN ルールで作成したデー夕は，研究者が研究現場で実際に使えるかということ の評価が必要である.すなわち, ルール化されたデー夕の有用性, 有効性の検証である。そこ で, 次のような課題について実証実験を行った。

\section{1 校訂本文データベース}

KOKIN ルールで記述したデータは，校訂本文データベースとして定義可能でかつ実装でき なければならない.とくに，作品の本文をどのようにデータベースに定義するかの問題がある. 本文の連続性を保存し, 文体の構造を規定し, 文や語や字の検索, 研究を可能としなければな 
らない.

校訂本文データベースは本文，書誌，注釈，ユーティリティという4つの実体とそれらの関 連により, 概念モデルが定義されている (安永 1994). すなわち, 図 1 に示した電子化本文の情 報構造を定義するモデルとして実現されている。

本文実体は，本文情報すなわち本文と傍記のデータベースである．作品単位でその本文情報 を蓄積するが，KOKIN ルール＃1で規定した論理レコードを定義域とする，KOKIN ルール \#2 は論理レコードを構成するデータとして取り扱う。書誌実体は本の構造を含む本情報であ る. 校訂本情報と文献資料情報のデータベースである。また，TTD のデータベースでもあり， 校訂本の目次構成や文書構造及び文体などの属性情報を持つ. 注釈実体は校註情報の内, 解説 註のデータベースである。ユーティリティ実体は校註情報の内, 校訂註を蓄積し, また校訂本 作成時の凡例に関する情報やシステム及び作品の利用案内情報を持つ.

実現の詳細は割愛するが，フルテキストを定義するデータモデルはないので，関係モデルを ベースに開発した，実装は HITAC M860/60 上に，DBMS に関係モデルである XDM（日立製 作所製）を用いた。本文の入れ子または階層構造や連続性は全て正規形に变換している。した がって，各関係表は多くのポインタ属性を持たざるを得ない。また，標準の SQLでは構造を持 つ文書に対して，例えば繰返し，入れ子などに関しての検索機能が不足である。そのため，文 書の論理構造を定義する DQL:Document Query Language(Hara and Yasunaga 1994) を考虑 している.

まず，案内的なディレクトリサービスを考えている．機能的にはダウンロードを可能とし， 文字列に基づく KWIC 索引作成などを行う。現在，国文学研究資料館において表 2 のデー夕 ベースの試行運用が行われている。

\subsection{CD-ROM の作成}

データ流通を一歩進めるものとして, KOKIN ルール記述のデータの CD-ROM 化, 並びに 検索サーバとして CD-ROM 上の必要な文字列を検索する機能システムについて検討した.

CD-ROM 検索サーバはソニー株式会社との共同研究により，同社の CD-ROM ハンドラで ある Media Finder をべースとした検索サーバと，その利用システムを開発した。検索サーバに ワークステーション（NEWS）を用いて，CSS として実装している。一方，MS-WINDOWSの 下でのパソコン版システムとして，サーバとユーザ機能を一体化した Media Finder（同一名称 である）を開発している。

CD-ROM の作成では Media Finder のデータ構造に，KOKIN ルールによる噺本大系の本文 デー夕を変換する必要がある。デー夕構造は単純化し， 2 階層とした，1枚の CD-ROM には 複数の Media Finder 型データベースが定義できる。また，データベースは項目と呼ぶ単位に分 類する。一般に，データベース中の項目数の制限はないが，多い場合は当然検索性能に関わる. 
Media Finder の設計思想は，項目単位で情報を高速に検索することに置かれている.

Media Finder はハイパーリンクに基づいた検索システムを持っており，噺本大系では 2 種 類の結合を生成している，1つは本文データの構造を定義する夕グを指標として，ハイパーリ ンクを構成したものである。これにより，本文の構成要素（全文，噺，注釈など）を単位とし た文字列検索が可能となる. 他の 1 つは, 論理ファイル単位（夕グ Pによる領域）を検索対象 とするものである。これにより, 校訂本の本文の表記を忠実に再現する，ただし，本文表記の 再現であり, ページ像は再現しない.

検索機能としては，次の機能を実装している。

(1) 目次検索: 関連する文章を辿りながら，ブラウジングする機能

(2) 文字または単語検索: 必要な語彙単位から情報を探す機能

(3) 項目検索: 項目名から必要な情報を検索する機能

(4) しおり：参照した項目に印を付け，後からそれを呼び出す機能

その他にも, 印刷や自前のファイルに取り込むこと, 関連する語彙から探すこと, 絵や表を取 り扱うことも可能としている.

このようなシステムを実装し，実験環境に供している，概して評判がよい.

\subsection{SGML 化}

KOKIN ルールは研究者が憶えやすく，使い易い規則として開発されているが，SGML と互 換性を持っている. SGML による古典本文や目録の構造記述はデータの標準化を一層推進する.

噺本大系, 正保版本歌集二十一代集などのデー夕記述を SGML で行った。噺本大系は KOKIN ルールで記述した本文データから, SGMLへの変換を行った. 正保版本歌集は独自仕様で記述 された本文データから, SGML 変換を行った. いずれも, SGML 仕様に基づいた DTD を定義 し, Mark-it (Sema Software Technology 社製) と言うSGML パーサにかけ，自動変換した。

DTD を如何にうまく定義するかがポイントである. KOKIN ルール＃1の変換は比較的簡単 である. KOKIN ルール２の変換は日本語の表記構造の認識にあるため, 困難な場合が多い. 例えば，傍記の泣き別れである（図 5 参照）。また，論理レコードの順序性の保持は, SGML での記述は難しい. 現在, 技術検討を行っている.なお，SGML 化の詳細は別途報告の予定で ある（例えば，(Hara and Yasunaga 1995))。

変換された SGML データは，例えば Mark-it でTex 形式のデー夕に変換し，印刷版面に 近い版下出力などが可能である. SGML から Tex への自動変換も行った. また, Open-Text (Open-Text 社製) と言うフルテキストデータベース検索システムを用いれば，DTD で定義さ れた要素を指定する語彙検索が可能である。これらは，現在試行実験を行っている。 


\section{6 あとがき}

国文学作品のテキストデー夕記述文法について述べた．全ての時代，ジャンルに渡る本文を， ここで述べたデー夕記述文法で記述できるわけではない．作品毎に細部の機能拡張が必要であ る、ただし，この骨格は有効であると考えている.

国文学では，作品の本文を同定すること，すなわち定本を確定することが極めて重要とされ る。ある作品の本は書写などによる永い伝搬過程を持っているから，本文それ自体に多くの異 動が発生している。諸本の系譜を知らなくては, 本文の確立あるいは解釈は成立しない。この ことを前提として，KOKIN ルールは作られている．また，KOKIN ルールでは校訂本を記述 できる。

KOKIN ルールは国文学者にとって取り扱いが容易な文法である.デー夕記述において，ユー ザ定義が容易であるため自由度が高く, 機能拡張性に富む.すでに, デー夕作成も始められて いる.

本文データベースの目的は，既定の活字本をコンピュータに写し取るのではなく，また本を 作ることでもない. 本文がコンピュータに入力されたとき, 研究の多様な展開に寄与できるこ とを目的としている。したがって，利用者が個人的に自由に活用できるデータベースでなけれ ばならない。 そのための試みとして, 大型コンピュータによるデータベースサービスの他に, CD-ROM 化についての検討も行っている.

なお，デー夕流通について，とくにJIS 外字の取り扱いは，現在有効適切な対策は立てられ ていない. 大きな将来課題である。

デー夕作成作業は多くの人手と時間と費用を要す。とくに，異なる多量な作品を対象として いるから, 深く広い専門的知識と有効適切なかつ総合的な作業管理を必要としている．とりわ け，デー夕の信頼性確保のための校正には多大の労力を強いられている.

最近，欧米を中心にフルテキストの標準化計画（TEI）が進められている．これは，現在の ところ英字を中心とする SGML に基礎を置く多様なドキュメント類のデータ流通，蓄積を目的 としているが, これへの日本語としての対応が求められている. 本稿でのデー夕記述文法は独 自なものであるが, 基本的考え方は共通である。また, 一部の作品については機能互換性を検 証している，ただし，国文学作品の全般に渡る標準化は極めて困難なことと考えている．本研 究がその一助となれば幸いである.

\section{謝辞}

本研究では，日頃ご指導いただく国文学研究資料館の佐竹昭廣館長，藤原鎮男教授，立川美 彦教授に御礼申し上げる，また，同館岡雅彦教授，中村康夫助教授には，有益な助言と批評な どをいただいた.とくに，原正一郎助教授，情報処理係野村龍氏をはじめ，係員諸氏には，シ ステム開発，実験などの協力をいただいた，また，ソニー株式会社三原節生氏，日本科学技術 振興財団小島哲郎氏始め, 多くの方々に, システム開発などに協力をいただいた，合わせて深 
謝する。

\section{参考文献}

勉誠社 (1993). 勉誠データセンタ利用の手引. 勉誠社.

Burnard, L. et.al. (1994). Guidelines for Electronic Text Encoding and Interchange(TEI P3), Vol. 1-3. ALLC,ACH,ACL.

DB-West 編 (1995). パソコン国語国文学. 啓文社 (京都).

Hara, S. and Yasunaga, H. (1994). "On the Full-text Database of Japanese Classical Literature." In $A L L C A C H 93$, pp. 61-64.

Hara, S. and Yasunaga, H. (1995). "On the Text Based Database for Public Data Service." In $A L L C A C H 95$, pp. 43-45.

伊井春樹 (1993). “国文学研究におけるコンピュータ利用.” 人文学と情報処理, 1, pp. 41-47. 伊藤鉄也 (1992). “源氏物語の情報処理.”源氏物語講座, 9, pp. 84-95. 勉誠社.

岩波書店 (1995). 新日本古典文学大系 CD-ROM 版八代集. 岩波書店.

JIS (1994). X-4151, 文書記述言語 SGML.

国文学研究資料館編 (1992). “国文学研究資料館の 20 年.”.

近藤泰弘 (1991). “古典文法の立場から考えた検索とテキスト.” 日本語学, 10 (11), 104-114.

村上学 (1989). “エンドューザの視点から.” 国文学とコンピュータシンポジウム講演集, $,(1), \mathrm{pp}$.

13-34. 国文学研究資料館.

長瀬真理 (1990). “日本語 - 英語対象「源氏物語」のテキストデータベースの作成に関する基礎 的研究." 情報知識学会誌, 1 (1), 40-53.

田嶋一夫・星野雅英 (1982). “本文研究の立場から見たテキストデータベースの機能について.”

情報処理学会自然言語処理研究会, 32-6, pp. 1-5.

内田保廣 (1992). “古典とコンピュータの最近の関係について. しにか, $3(2), 10-15$.

Yasunaga, H. (1992). "Data Description Rule and Full-text Data-base for Japanese Classical

Literature." In ALLCACH92, pp. 234-239.

安永尚志 (1994). “日本古典文学の本文データベース.”情報処理学会誌, 35 (7), 942-650.

安永尚志 (1995a). “国文学研究とコンピュータ.”言語処理学会第 1 回大会 発表論文集, pp. 11-20.

安永尚志 (1995b). “日本古典文学作品フルテキストデータベースのためのデータ記述文法に関 する実証的研究.”. 科学研究費報告書 \#03402051. 


\section{付録}

\section{A 国文学の用語}

主として，広辞苑（1983，岩波書店，第三版）により，読みの $\mathrm{ABC}$ 順で示す。

梵字 (ボンジ) ：梵語すなわちサンスクリットを記載するのに用いる文字.

伝本 (デンポン)：ある文献の写本または版本として世に伝存するもの.

絵詞 (エコトバ)：絵を説明した詞. 絵巻物の詞書き。絵解きの詞.

翻刻 (ホンコク)：手書き文字，木版文字などを活字に置き換えること.

翻刻本とは，写本，刊本を底本として，木版または活版で刊行した本。

異本 (イホン) : 同一の書物であるが, 文字, 語句, 順序に異同があるもの. 別本.

解題 (カイダイ) : 書物や作品の著作者, 著作の由来, 内容, 出版の年月などの解説.

掛詞（カケコトバ）：同音異義を用いて，1 語に 2 つ以上の意味を持たせたもの.

囲み(カコミ) : 紙面の一部を枠で囲んだ部分。虫喰いの痕など.

刊本 (カンポン) : 狭義には主として江戸時代の木活字本, 銅活字本, 整版本などの称. 版本.

校異 (コウイ ) : 文章の文字, 語句を比べ合わせ, 調べること.またその結果.

訓点 (クンテン) : 漢文を訓読するために原文に書き加えた文字, 符号の称.

虫喰い(ムシクイ $：$ 紙魚などによる食害.

踊り字 (オドリジ) ：熟語で同一の漢字または仮名を重ねることを表す符号．重ね字．

底本 (テイホン) : 翻訳，校訂などに当たって主な拠り所とした本。そこほん。

頭註（トウチュウ）：本文の上方に註を付すこと．また，その註．脚註もある．

謡印 (ウタイジルシ) : 謡曲の謡の印.

割書 (ワリガキ) ：本文の途中に 2 行以上に小さく注などを書き入れること.

ヨコト点 ：漢文訓読で漢字の読みを示すため，文字の隅などに付けた点や線の符

号. その位置と形で読みが決まる. 広く, 訓点の 1 種と考えられる. 


\section{B 噺本大系の作品構造 (TTD の例)}

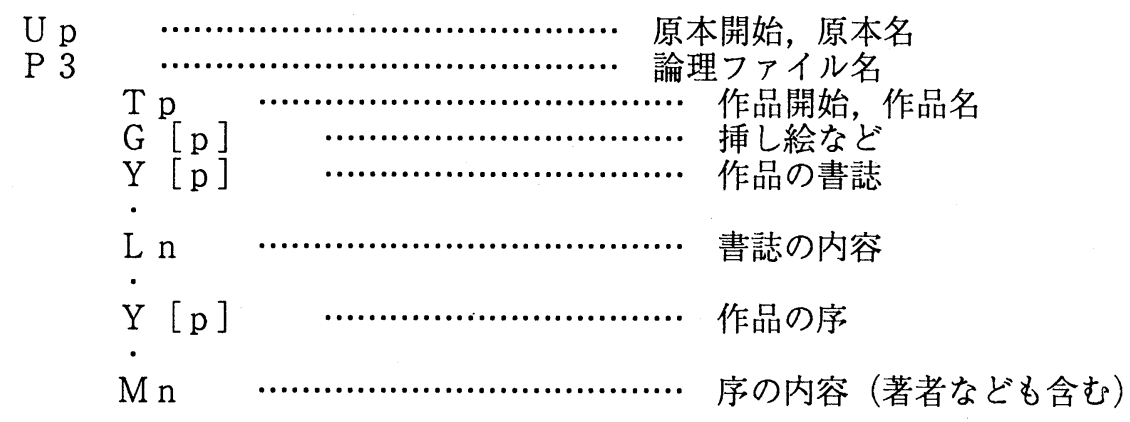

P 7

P 11

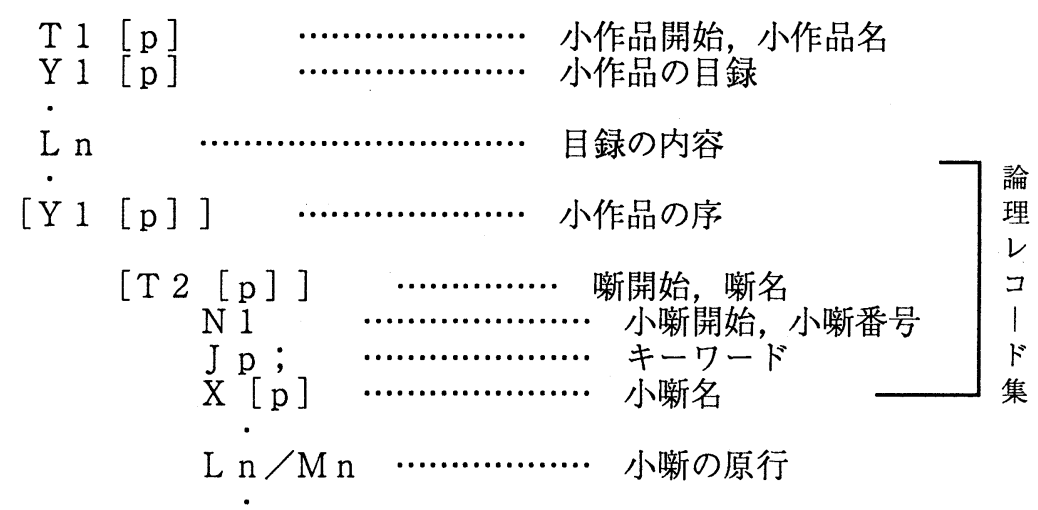

P 23
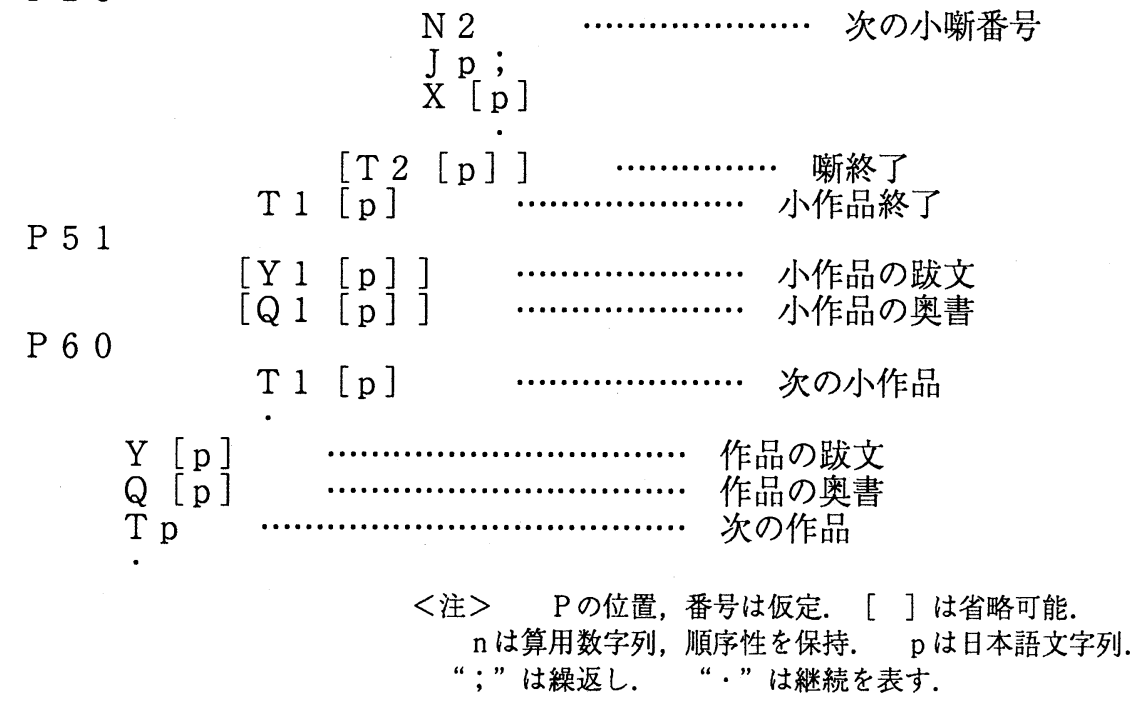


\section{C 噺本大系第 5 巻「軽口大わらひ」のデータ記述例}

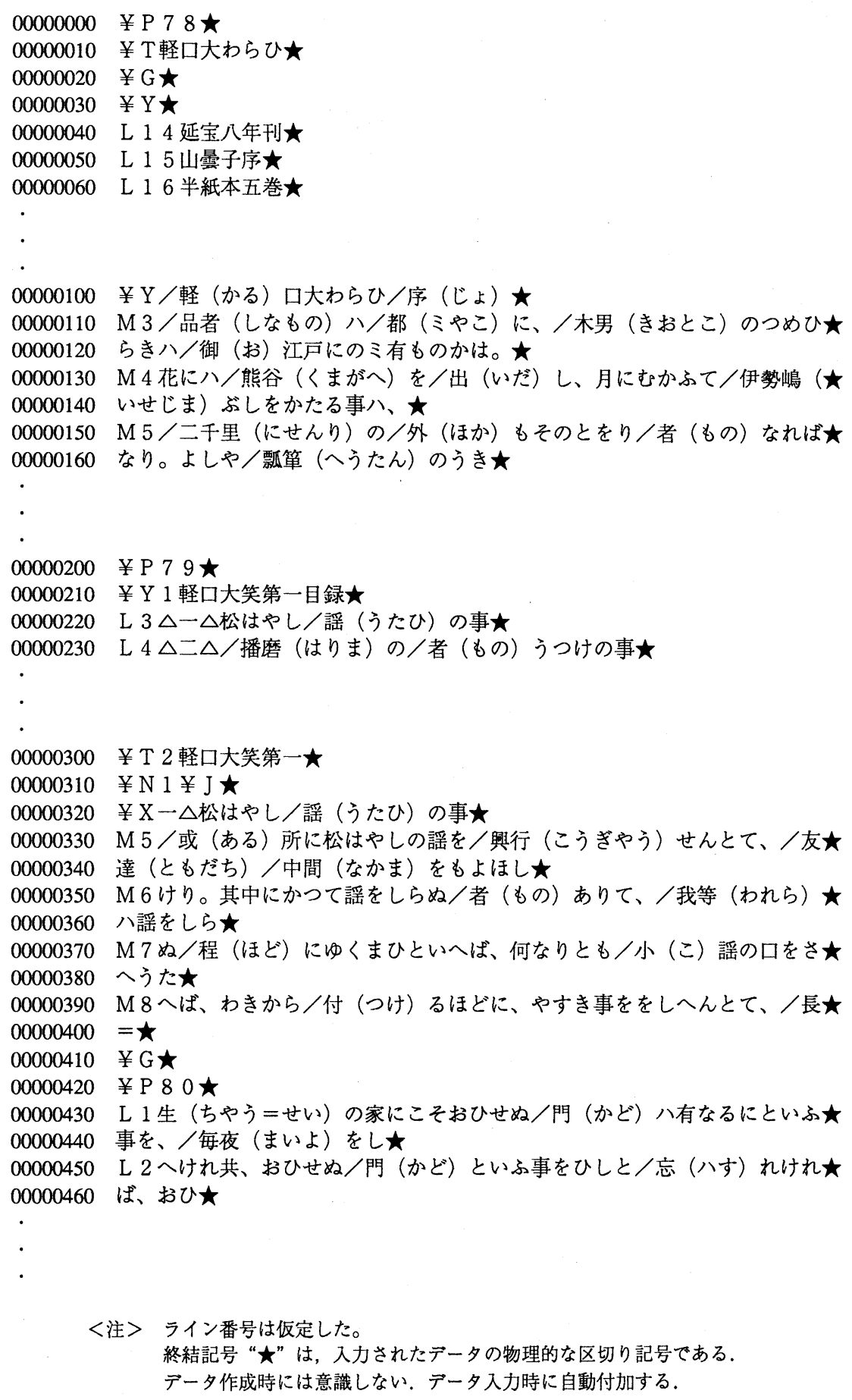




\section{略歴}

安永尚志: 1966 年電気通信大学電気通信学部卒業. 同年電気通信大学助手, 東 京大学大型計算機センター助手, 同地震研究所講師, 文部省大学共同利用機 関国文学研究資料館助教授を経て, 1986 年より同館教授. 工学博士. 情報通 信ネットワークに興味を持っている. 現在人文科学へのコンピュータ応用に 従事.とくに，国文学の情報構造解析，モデル化，データベースなどに関す る研究と応用システム開発を行っている. 最近では, テキストデータベース の開発研究に従事. 電子情報通信学会, 情報知識学会, 情報処理学会, 言語 処理学会, ALLC, ACH など会員.

(1995 年 8 月 31 日 受付)

(1996 年 1 月 11 日 再受付)

(1996 年 2 月 20 日 採録) 